\title{
Correspondence
}

\section{Divided doses of methohexitone improves ECT outcome}

\section{To the Editor:}

We read with interest the recent report on substitution of mivacurium for succinylcholine for ECT treatment. ${ }^{1}$ Since the effect of mivacurium outlasts the effect of methohexitone (MH) the authors suggested reversal of the neuromuscular block after treatment to avoid awareness.

While we are unaware of a correlation between the length of seizures and the antidepressant effect of ECT, the duration of grand mal seizures is thought to be important. ${ }^{2}$ Occasionally, when using lower doses of $\mathrm{MH}$, we have also experienced awareness upon recovery. Further increase of the MH dose to prevent recall shortens the duration of seizures, especially in older patients. To solve this problem we decided to split the total amount of $\mathrm{MH}$ to be injected $\left(0.65-0.8 \mathrm{mg} \cdot \mathrm{kg}^{-1}\right)$ into two doses. The first (75\% of the assigned dose of $\mathrm{MH}$ ) is given together with succinylcholine $\left(0.8-1.0 \mathrm{mg} \cdot \mathrm{kg}^{-1}\right)$ before electrical stimulation and the remainder immediately after the convulsions. Labctalol and/or glycopyrrolate are used as indicated. We have observed that with the lower first dose of $\mathrm{MH}$ the duration of seizures has increased by $16.7 \%(52 \pm 4 \mathrm{sec}$ vs $31 \pm 3 \mathrm{sec}$ ). For the last five months the proposed technique was successfully used 146 times on 17 patients of different ages without any complications.

\section{Simon Gurmarnik MD}

Department of Anesthesiology

Richard Young MD

Eugenya Alcsker MD

Center for Behavior Medicine

Southwood Community Hospital

III Dedham St.

Norfolk, MA 02056

\section{REFERENCES}

1 Janis $K$, Hess J, Fabian JA, Gillis $M$. Substitution of mivacurium for succinylcholine for ECT in elderly patients. Can J Anaesth 1995; 42: 612-3.

2 Onosonn JO. Seizure characteristics and therapeutic efficacy in electroconvulsive therapy: an analysis of the antidepressive efficiency of grand mal and lidocaine moditied seizures. J Nerv Ment Dis 1962: 135: 239-51.

\section{REPLY}

We share their concern about short acting anesthetics for ECT which might create conditions facilitating awareness. However, our use of active reversal of the neuromuscular block was intended to avoid subile airway problems when a non-depolarizing relaxant was used for short procedures. This was of particular concern to us since our patients were predominantly elderly with systemic illness which would compromise their ability to compensate for residual weakness.

We have also used incremental doses of methohexital to assure lack of awareness. Recent work suggests that perhaps etomidate could replace methohexital to allow for a longer seizure duration along with slower awakening.'

Kenneth M. Janis MD

Associate Professor of Anesthesiology

University of New Mexico

REFERENCE

I Avramov MN, Husain MM, White PF. The comparative effects of methohexital, propofol and etomidate for electroconvulsive therapy. Anesth Analg 1995; 81: 596-602.

\section{Midazolam for caudal analgesia in children}

To the Editor:

In an editorial' which accompanied our article, ${ }^{2}$ Dr. Goresky, expressed several concerns and doubt about the clinical utility of caudal midazolam for postoperative analgesia in children. He also raises several questions that warrant answers. In the Kingdom of Saudi Arabia, the rules and regulations that govern the approval of a new drug or a new route of application of an existing drug are very stringent. The regulatory body (Ministry of Health) is different from that in North America (USA and Canada). Additionally, in our institution (King Khalid University Hospital and King Saud University) the approval of the CMRC (College of Medicine Research Council) and the Pharmacy and Therapeutic Committee are mandatory for any research proposal. Our sludy was not conducted under sponsorship of the manufacturer. Nevertheless, even if this study were supported by the manufacturer, the review process would have been the same.

Dr. Goresky chose to ignore the information provided in our paper regarding the safety of both intrathecal and epidural midazolam in primates (as he suggested) and in humans. He quoted only one study in his editorial that reported changes in the blood-brain barrier after administration of very large doses of midazolam intracisternally in rabbits $(0.3 \mathrm{ml}$ of $0.1 \%$; equivalent to $\left.111 \mu \mathrm{g} \cdot \mathrm{kg}^{-1}\right) .{ }^{3}$ We addressed the limitations of this study in our paper and pointed out that even high concentrations of lidocaine can produce neurotoxic effects in humans. ${ }^{4.5}$ We wonder why Dr. Goresky did not refer to the remaining 18 studies in the literature (Medline search reveals 17 published papers in addition to another study that appeared in a chapter of a book)? The safety and the efficacy of neuraxial application of midazolam have been invariably demonstrated in all of these studies, both in humans after intrathecal (3 studies) and epidural (6 studics) administration as well as in different species of animals (rats, rabbits and dogs). Due to limitations of the spacc availability, we referred to some (but not all) of these studies in our paper.

Similarly, scveral studies have shown that the analgesic effect of neuraxial administration of midazolam was due to antinociceptive propertics of midazolam but not due to sedition (see, for example ${ }^{6.7}$ ). 